\title{
Modifications of phosphocaseinate solutions treated by selective adsorption
}

\author{
Nathalie Martin ${ }^{\mathrm{a}, *}$, Rafael Jiménez-Flores ${ }^{\mathrm{b}}$, Phillip S. Tong ${ }^{\mathrm{b}}$, Yves Pouliot ${ }^{\mathrm{a}}$, Michel Britten $^{\mathrm{c}}$ \\ ${ }^{a}$ Centre de recherche STELA, Départment de Sciences des Aliments de Nutrition, Université Laval, Québec, Canada GIK 7P4 \\ ${ }^{\mathrm{b}}$ Dairy Products Technology Center, California Polytechnic State University, San Luis Obispo, CA 93407, USA \\ ${ }^{\mathrm{c}}$ Food Research and Development Center, Agri-Food Canada, St-Hyacinthe, Québec, Canada J2S 8E3
}

\begin{abstract}
The treatment of phosphocaseinate by adsorption with diatomaceous earths has been studied. The results suggest that magnesium and calcium silicates have a specific affinity for milk proteins. As a result, the ratio of individual casein types in phosphocaseinate solution can be manipulated.
\end{abstract}

Keywords: Microfiltration; Casein micelles; Adsorption; Silicates

\section{Introduction}

New membrane processes allow the preparation of milk protein products containing different ratios of casein fractions, whey proteins and mineral, with particular physicochemical and functional properties. Diatomaceous and synthetic silicates are often used as active filter aid agents in the deep-fat frying industry, and have also been found to be capable of inducing physical changes in the milk fat. A process was developed for cholesterol removal by means of saponins (Richardson \& Jiménez-Flores, 1989). The removal of this complex was achieved through selective adsorption using diatomaceous silicates. A specific affinity for milk fat globule membrane's phospholipids was also reported by Choi and Jiménez-Flores (1992). These observations were related to previous observations on changes in the physical properties and functionally of cream upon treatment with silicates.

The aim of this preliminary work was to study modifications to phosphocaseinate induced by adsorption treatment with diatomaceous earths.

\section{Materials and methods}

Phosphocaseinate (PPCN) was prepared by microfiltration $(3.5 \mathrm{X})$ of skim milk using a $0.1 \mu \mathrm{m}$ pore diameter
Membralox membrane, according to Pierre, Fauquant, Le Graet, Piot and Maubois (1992). This PPCN enabled to work with a micellar casein system close to that of the native state in milk. PPCN was rehydrated to 5\% $(\mathrm{w} / \mathrm{v})$ total protein, and treated with $10 \%(\mathrm{w} / \mathrm{w})$ of three kinds of diatomaceous silicates, synthetic calcium and magnesium silicate (World Minerals, Celite Corporation, California). The adsorbers were separated from the liquid substrates and washed by centrifugation and filtration steps. The adsorbed material was collected using a dissociating buffer. Each treatment was performed in triplicate.

\section{Results}

The $\mathrm{pH}$ of PPCN solutions ( $\mathrm{pH}$ 6.8-7.0) was not affected by the treatment with diatomaceous silicates. In fact, diatomaceous silicates are almost essentially composed of silica and are known to be inert to most chemical reactions. The adsorption process involving magnesium or calcium silicates did, however, increase the $\mathrm{pH}$ of PPCN solutions. The $\mathrm{pH}$ increases were slight in the case of magnesium silicates ( $\mathrm{pH} 7.0-7.5)$ but up to 9.5-10.5 with calcium silicates. The release of minerals by these adsorbents was assesed in deionized water, using capillary electrophoresis (data not shown). Results indicate significant concentration of calcium in water after treatment with calcium silicates and a high content of magnesium when treated with magnesium silicate. No release 
was detected with diatomaceous silicates. It is suggested that an ion-exchange type chemical reaction can occur explaining the presence of $\mathrm{Ca}^{2+}$ or $\mathrm{Mg}^{2+}$ in these solutions which increase $\mathrm{pH}$. These $\mathrm{pH}$ changes could depend upon the concentration of active sites and/or the dissociation constants of the adsorbent.

The amount of total protein adsorbed on diatomaceous earths was evaluated by Kjeldahl analysis. Magnesium silicate showed the highest affinity for protein with $12.5 \%$ protein adsorbed compared to $6.2-9.1 \%$ for calcium silicates and $6.1-1.4 \%$ for diatomaceous silicates. Calcium or magnesium silicates, in spite of their filtration properties for the deep-fat frying industry, are also used for the removal of polar compounds that are the result of degradation of oils (Zhu, Yates \& Caldwell, 1994). These adsorbents can bind, via chemisorption, compounds like free fatty acids through acid and/or basic sites of silicates. The magnesium silicate always shows the highest amount of compounds adsorbed (Zhu et al., 1994).

SDS-PAGE analyses (SDS reducing buffer, $\mathrm{pH}$ 6.8) revealed that magnesium silicate had specific affinity for $\alpha_{\mathrm{s}}$-casein and $\beta$-lactoglobulin but not for $\beta$ and $\kappa$-caseins. The protein profile of the material adsorbed on calcium silicate can bind the three casein fractions but showed a greater affinity for $\kappa$-casein and some of high molecular weight proteins, presumably from the fat globule membrane. The second kind did not seem to have strong affinity for casein fractions but could bind more specifi- cally, $\beta$-lactoglobulin. The profile of proteins in the material adsorbed onto the diatomaceous silicates was similar to that of PPCN. Because of the 'neutrality' and the high porosity of these adsorbents, the proteins may be entrapped into the structure.

These preliminary results suggest that magnesium and calcium silicates possess a specific affinity for some milk proteins, and depending upon the adsorbent involved, the caseins ratio of a PPCN solution can be changed. More work needs to be done, however, in order to better understand the interaction between the adsorbent and its surrounding environment but also to relate the changes to the functionality of treated products.

\section{References}

Choi, J. H., \& Jiménez-Flores, R. (1992). Milk fat globule membrane modification from adsorption treatment with inorganic materials. Annual ADSA Meeting, Ohio State University, Columbus, OH, June 21-24.

Pierre, A., Fauquant, J., Le Graet, Y., Piot, \& Maubois, J.-L. (1992). Préparation de phosphocaséinate natif par microfiltration sur membrabne. Lait, 72, 461-474.

Richardson, T., \& Jiménez-Flores, R. (1989). Process to remove cholestrol from dairy products. US Patent Number 5,326,579, Awarded, June 1994.

Zhu, Z. Y., Yates, R. A., \& Caldwell, J. D. (1994). The determination of active filter aid adsorption sites by temperature-programmed desorption. Journal of the American Oil Chemists Society, 71, 189-194. 